DOI: https://doi.org/10.24127/ajpm.v10i1.3375

\title{
PENGEMBANGAN MODUL TRIGONOMETRI UNTUK MENGEMBANGKAN KEMAMPUAN PEMECAHAN MASALAH MATEMATIKA
}

\author{
Rahmatya Nurmeidina ${ }^{*}$, Ahmad Lazwardi², Arif Ganda Nugroho ${ }^{3}$ \\ ${ }^{1 * 2,3}$ Pendidikan Matematika, Universitas Muhammadiyah Banjarmasin, Indonesia. \\ ${ }^{*}$ Corresponding author \\ E-mail: $\quad$ rahmatya.dina@gmail.com ${ }^{1 *}$ \\ lazwardiahmad@gmail.com $^{2)}$ \\ arif.gnugroho@gmail.com $^{3}$ )
}

Received 10 December 2020; Received in revised form 28 February 2021; Accepted 01 April 2021

\begin{abstract}
Abstrak
Pemecahan masalah merupakan salah satu kempauan yang sangat penting dimiliki oleh mahasiswa calon guru matematika. Salah satu cara untuk mengembangkan kemampuan pemecahan masalah mahasiswa adalah dengan menggunakan pembelajaran menggunakan modul yang didesain untuk mengembangkan kemampuan pemecahan masalah. Penelitian ini bertujuan untuk mengembangkan modul trigonometri untuk mengembangkan kemampuan pemecahan masalah mahasiswa pendidikan matematika yang valid, praktis, dan efektif. Penelitian ini merupakan penelitian pengembangan (Research \& Development). Penelitian ini mengembangkan modul mata kuliah trigonometri dengan menggunakan model pengembangan 4D (Define, Design, Develop, Dessiminate). Instrumen yang digunakan terdiri dari lembar validasi yang diisi oleh ahli bidang pendidikan matematika, lembar penilaian kepraktisan mahasiswa, dan tes hasil belajar dengan soal pemecahan masalah. Kualitas modul yang dikembangkan ditinjau dari aspek kevalidan, aspek kepraktisan dan aspek keefektifan. Hasilnya adalah modul termasuk pada kategori valid, dengan nilai kepraktisan pada kategori tinggi. Aspek efektifitas berdasarkan tes hasil belajar dengan soal pemecahan masalah mengalami peningkatan ditinjau dari hasil pretest dan post test. Hasil pengembangan dalam penelitian ini adalah produk modul pembelajaran mata kuliah trigonometri yang valid, praktis dan efektif dan layak digunakan untuk mahasiswa pendidikan matematika. Kontribusi dari penelitian ini adalah modul ini dapat digunakan ketika perkuliahan Trigonometri.
\end{abstract}

Kata kunci: Modul; pengembangan; pemecahan masalah; trigonometri.

\begin{abstract}
Problem-solving is one of the most important abilities possessed by prospective mathematics teacher students. One way to develop student problem-solving abilities is to use learning models designed to develop problem-solving abilities. This study aims to develop a trigonometry module to develop valid, practical, and effective mathematics education student problem-solving abilities. This research is a research development (Research \& Development). This study develops a trigonometric course module using the $4 D$ development model (Define, Design, Develop, Disseminate). The instruments used consisted of validation sheets filled out by experts in the field of mathematics education, student practicality assessment sheets, and learning outcomes tests with problem-solving questions. The quality of the developed modules is viewed from the aspects of validity, aspects of practicality, and aspects of effectiveness. The result is that the module is included in the valid category, with a high practicality value. The aspect of effectiveness based on test learning outcomes with problem-solving problems has increased from the results of the pretest and posttest. The result of the development in this study is the product of a trigonometric course learning module that is valid, practical and effective, and suitable for use by mathematics education students. The contribution of this research is that this module can be used during Trigonometry lectures.
\end{abstract}

Keywords: Development; module; problem solving; trigonometry..

This is an open access article under the Creative Commons Attribution 4.0 International License 
DOI: https://doi.org/10.24127/ajpm.v10i1.3375

\section{PENDAHULUAN}

Trigonometri merupakan mata kuliah dasar yang sangat penting dalam program studi pendidikan matematika. Trigonometri menyediakan banyak peluang pemecahan masalah dan melibatkan kemampuan penalaran dan pembuktian. Ini menggabungkan aljabar dan geometri, dan berisi representasi visual. Juga, persamaan trigonometri digunakan dalam topik selanjutnya, seperti bilangan kompleks, batas, turunan, dan integral. Oleh karena itu, sangat penting bagi siswa untuk menguasainya agar lebih kompeten dalam matematika (Sarac \& AslanTutak, 2017). Kapasitas penguasaan trigonometri menjadi prasyarat untuk penguasaan matematika tingkat lanjut (May \& Courtney, 2016).

Pemecahan Masalah merupakan satu kemampuan dasar dalam pembelajaran matematika, membantu individu berpikir analitik, belajar pemecahan masalah matematis, pada hakikatnya adalah belajar berpikir, bernalar dan menerapkan pengetahuan yang telah dimiliki, pemecahan masalah matematis membantu berpikir kritis, kreatif dan mengembangkan kemampuan pemecahan masalah matematika lainnya (Hendriana et al., 2017). Adapun Polya (Polya, 2004); (In'am, 2015) menyatakan bahwa penyelesaian masalah matematika dapat diimplementasikan dalam empat tahap yaitu: memahami masalah, merencanakan strategi pemecahan masalah, melaksanakan pemecahan masalah dan mereview kembali hasil yang diperolehnya.

Kemampuan pemecahan masalah penting untuk dimiliki mahasiswa pendidikan matematika sebagai calon guru. Berdasarkan Permendiknas No 22 tahun 2006 pembelajaran matematika bertujuan agar peserta didik memiliki kemampuan memahami konsep matematika, menjelaskan keterkaitan antar konsep dan mengaplikasikan konsep atau algoritma, secara luwes, akurat, efisien, dan tepat, dalam pemecahan masalah. Salah satu kompetensi yang penting untuk mencapai tujuan tersebut adalah kemampuan pemecahan masalah. Kemampuan pemecahan masalah merupakan hal yang penting untuk dimiliki oleh setiap peserta didik dan merupakan dasar dalam mempelajari maupun menerapkan matematika. Seorang guru atau calon guru matematika dituntut mampu merancang pembelajaran yang mampu mengeksplorasi pemecahan masalah (Nugroho et al., 2018). Oleh karena itu, mahasiswa pendidikan matematika sebagai calon guru juga harus memiliki kemampuan pemecahan masalah dan dapat mengeksplorasi pemecahan masalah dalam pembelajaran di kelas.

Mahasiswa masih kesulitan dalam menyelesaikan soal trigonometri terutama pada soal-soal pemecahan masalah (Nurmeidina \& Rafidiyah, 2019). Trigonometri merupakan topik yang sulit dipahami oleh guru dan siswa (May \& Courtney, 2016) selain itu mahasiswa juga mengalami kesalahan miskonsepsi (Ahmad et al., 2018). Kesalahan dalam mengerjakan soal pemecahan masalah yang sering terjadi (Phonapichat et al., 2014) dijelaskan bahwa 1) Siswa mengalami kesulitan dalam memahami kata kunci yang muncul dalam masalah, sehingga tidak dapat menafsirkannya kalimat matematika. 2) Siswa tidak dapat menentukan apa yang harus diasumsikan dan informasi apa dari masalah yang diperlukan untuk menyelesaikannya, 3) Setiap kali siswa tidak memahami masalah, mereka cenderung menebak jawabannya tanpa 
proses berpikir, 4) Siswa tidak sabar dan tidak suka membaca soal matematika, dan 5) Siswa tidak suka membaca soal yang panjang. Berdasarkan beberapa hasil penelitian terdahulu soal pemecahan masalah masih dianggap sulit oleh sebagian besar siswa.

Untuk meningkatkan kemampuan pemecahan masalah mahasiswa tersebut diperlukan peran penting dari dosen untuk memberikan fasilitas kepada mahasiswa untuk mengembangkan kemampuan pemecahan masalah. Pada pembelajaran di perguruan tinggi, dosen sangat berperan untuk mengkondisikan perkuliahan dengan metode yang tepat, salah satunya adalah dengan membuat modul (Nurmeidina et al., 2020). Dengan adanya modul pembelajaran dapat memudahkan mahasiswa berlatih soal-soal kemampuan pemecahan masalah secara mandiri. Pembelajaran matematika menggunakan modul efektif (Devesh \& Nasseri, 2014) dan dapat meningkatkan kemampuan pemecahan masalah siswa (Nasution, 2016), (Subekti \& Akhsani, 2020). Berdasarkan penelitian-penelitian terdahulu tersebut. Dapat dilihat bahwa modul pembelajaran bisa menjadi solusi yang baik untuk meningkatkan kompetensi mahasiswa khususnya dalam kemampuan pemecahan masalah. Sejauh ini pembelajaran trigonometri menggunakan masih belum menggunakan modul yang dibuat dosen. Oleh karena itu, pengembangan modul pemebelajaran perlu untuk dilakukan.

Penelitian sebelumnya Modul Matematika Berdasarkan Model Pembelajaran Problem Based Learning Materi Pokok Trigonometri memperoleh hasil validasi kriteria valid. Pada uji coba lapangan memperoleh kriteria sangat menarik. (Angraini \& Masykur, 2018) dan Pengembangan
Modul Pembelajaran Matematika Berbasis Masalah untuk Meningkatkan Kemampuan Pemecahan Masalah materi trigonometri SMA kelas $\mathrm{X}$ mendapatkan hasil uji pengembangan: modul matematika berbasis masalah memenuhi predikat valid, praktis, serta efektif digunakan. (Sormin \& Sahara, 2019). Selain itu, penelitian sebelumnya yang sama-sama menggunakan subjek mahasiswa pendidikan matematika yaitu pengembangan modul trigonometri bercirikan open ended problem dan menggunakan pendekatan Scientific Learning dengan sintaks yaitu mengamati, menanya, menggali informasi, mengasosiasi, dan mengkomunikasikan. Hasil penelitian ini adalah modul, instrumen dan RPP yang dikembangkan telah memenuhi kriteria valid, praktis dan efektif (Ismail et al., 2017).

Kebaruan dari modul yang dikembangkan dalam penelitian ini adalah modul ini merupakan modul mata kuliah trigonometri untuk mahasiswa yang berorientasi untuk mengambangkan kemampuan pemecahan masalah mahasiswa sehingga soalsoal pada modul dirancang untuk melatihkan kemampuan pemecahan masalah. Soal-soal pada modul ini terdiri dari contoh soal, latihan soal dengan petunjuk jawaban dan latihan soal dengan kunci jawaban. Dengan demikian, tujuan penelitian pengembangan ini yaitu (1) menghasilkan modul trigonometri untuk mahasiswa pendidikan matematika yang valid, praktis dan efektif dan (2) mendeskripsikan kevalidan, kepraktisan dan keefektifan modul pembelajaran trigonometri untuk meningkatkan hasil belajar dan disposisi matematis mahasiswa pendidikan matematika. 


\section{METODE PENELITIAN}

Penelitian ini adalah penelitian pengembangan (Research \& Development). Modul yang akan dikembangkan dalam penelitian ini adalah modul mata kuliah trigonometri untuk mengembangkan kemampuan pemecahan masalah mahasiswa pendidikan matematika. Model pengembangan menggunakan model Four-D (4-D) yang terdiri dari empat tahap pengembangan, yaitu Define (pendefinisian), Design (desain), Develop (pengembangan), Desseminate (penyebaran) (Thiagarajan et al., 1976). Untuk memperoleh prototipe berkualitas, hasil dari penelitian pengembangan perlu dilakukan uji kualitas. Kualitas prototipe dapat dilihat dari aspek kevalidan, kepraktisan, dan keefektifan.

Aspek Kevalidan merupakan penilaian dari validator berpendidikan doctor dalam bidang pembelajaran matematika dan trigonometri. Aspek kepraktisan merupakan penilaian dari mahasiswa setelah mendapatkan pembelajaran menggunakan modul. Aspek keefektifan dilihat dari hasil belajar siswa menyelesaikan soal pemecahan masalah setelah menggunakan modul.

Prosedur pengembangan pada penelitian ini didasarkan pada model pengembangan yang telah dipilih. Penelitian ini difokuskan pada pengembangan atau desain produk berupa modul trigonometri untuk kemampuan pemecahan masalah matematika. Langkah-langkah pada prosedur ini sebagai berikut:

1) Tahap pendefinisian, menentukan masalah dasar dan menetukan materi dan tujuan modul trigonometri.

2) Tahap Perancangan, pembuatan dan penulisan draft modul.
3) Tahap Pengembangan, validasi ahli oleh doktor bidang pembelajaran matematika dan peneliti bidnag trigonometri/geometri, analisis data validasi dan revisi awal, uji coba, analisis data hasil uji coba dan revisi akhir.

Instrumen penelitian terdiri dari lembar validasi modul, lembar penilaian modul dan soal trigonometri untuk mengukur kemampuan pemecahan masalah mahasiswa. Lembar validasi modul diisi oleh validator untuk mendapatkan data hasil validasi. Lembar penilaian modul diisi oleh mahasiswa untuk mendapatkan data kepraktisan hasil uji coba. Soal trigonometri dikerjakankan oleh mahasiswa setelah pembelajaran menggunkan modul untuk mengetahui keefektifan modul dalam mengembangkan kemampuan pemecahan masalah mahasiswa pendidikan matematika.

Adapun teknik analisis data yang dilakukan mengikuti prosedur berikut. Kevalidan dilihat dari nilai rata-rata total aspek penilaian berdasarkan langkah-langkah berikut :

1) Menentukan nilai rerata total dari rerata nilai untuk semua aspek $(V a)$ dengan rumus

$$
V a=\frac{\sum_{i=1}^{n} A_{i}}{n}
$$

dengan $A_{i}$ adalah nilai untuk aspek ke-i dan $\mathrm{n}$ adalah banyaknya aspek.

2) Nilai $V a$ ini dirujuk pada interval penentuan tingkat kevalidan yang dapat dilihat pada Tabel 1 .

Tabel 1. Kategori tingkat kevalidan

\begin{tabular}{ccc}
\hline No & Rentang & Kategori \\
\hline 1 & $1 \leq V a<2$ & Tidak valid \\
2 & $2 \leq V a<3$ & Kurang valid \\
3 & $3 \leq V a<4$ & Valid \\
4 & $V a=4$ & Sangat valid \\
\hline
\end{tabular}


DOI: https://doi.org/10.24127/ajpm.v10i1.3375

Analisis data penilaian mahasiswa mengikuti langkah yang sama seperti analisis data kevalidan. Aspek kepraktisan $(P r)$ merujuk pada kategori penilaian mahasiswa pada Tabel 2 .

Tabel 2. Kategori tingkat kepraktisan

\begin{tabular}{lcl}
\hline No & Rentang & Kategori \\
\hline 1 & $1 \leq \operatorname{Pr}<2$ & Sangat rendah \\
2 & $2 \leq \operatorname{Pr}<3$ & Rendah \\
3 & $3 \leq \operatorname{Pr}<4$ & Tinggi \\
4 & $\operatorname{Pr}=4$ & Sangat tinggi \\
\hline
\end{tabular}

Analisis data tes soal pemecahan masalah menggunakan rubrik penilaian. Teknil analisis data untuk melihat efektifitas adalah dengan melihat perkembangan kemampuan pemecahanan masalah. Kemampuan pemecahan masalah dikatakan berkembang jika mahasiswa mengalami peningkatan nilai dari soal pretest dan posttest hasil belajar dengan soal pemecahan masalah. Soal pretest adalah soal yang diberikan kepada mahasiswa sebelum pembelajaran menggunakan modul trigonometri yang telah dikembangkan, sedangkan Soal posttest adalah soal yang diberikan kepada mahasiswa setelah pembelajaran menggunakan modul trigonometri yang telah dikembangkan.

\section{HASIL DAN PEMBAHASAN}

\section{Deskripsi Tahap Pendefinisian}

Hasil yang didapatkan pada tahap pendefinisian adalah sebagai berikut:

\section{a. Analisis Awal-Akhir}

Data analisis awal akhir ini didapat dari hasil wawancara dengan ketua program studi pendidikan matematika, survei pendahuluan dan wawancara dengan pengampu mata kuliah trigonometri, survei pendahuluan kepada mahasiswa yang sudah pernah mengambil mata kuliah trigonometri dan wawancara dengan guru SMA pengajar mata pelajaran matematika.

Berdasarkan hasil wawancara dengan ketua program studi didapatkan informasi sebagai berikut: 1. Bahwa trigonometri merupakan mata kuliah semester 1. 2. Mata kuliah ini berisi tentang konsep sudut dalam derajat dan radian, konsep sinus kosinus dan tangen, identitas trigonometri, fungsi trigonometri, rumus trigonometri untuk jumlah dan selisih dua sudut, konsep trigonometri untuk sudut rangkap, aturan trigonometri, persamaan dan pertidaksamaan trigonometri. 3 . Diharapkan dosen pengampu trigonometri, tidak hanya mengajarkan konsep trigonometri saja. Kemampuan pemecahan masalah sangat penting diajarkan oleh dosen kepada mahasiswa. 4. Diharapkan dosen memiliki bahan ajarnya sendiri untuk memudahkan mahasiswa belajar.

Berdasarkan hasil wawancara dengan dosen pengampu didapatkan informasi bahwa: 1) dosen mengajar menggunakan buku yang sudah ada, belum sempat membuat modul atau bahan ajar sendiri, 2) dosen lebih sering mengajarkan tentang pemahaman konsep dan asal-usul rumus, jarang mengajarkan tentang kemampuan pemecahan masalah, 3) sesekali pernah memberikan soal kemampuan pemecahan masalah, Kemampuan menjawab soal pemecahan masalah masih kurang dimiliki mahasiswa.

Berdasarkan survei pendahuluan kepada dosen pengampu trigonometri selain dari kampus peneliti adalah: 1 . Sebagian dosen menggunakan buku yang sudah ada, dan sebagian lagi membuat bahan ajar sendiri berupa materi, penyelesaian dan soal. 2 . Kemampuan pemecahan masalah mahasiswa masih rendah. Dalam melatihkan soal pemecahan masalah 
kepada mahasiswa, pertama kali harus di bimbing terlebih dahulu. Setelah itu diberikan soal dengan sama kemudian ditingkatkan lagi permasalahannya. 3 . Penggunaan modul dalam pembelajaran trigonometri efektif. Jika modul itu diberi berbagai macam contoh penyelesaian dan soal.

Berdasarkan hasil survei pendahuluan kepada mahasiswa diperoleh informasi bahwa 8 dari 12 mahasiswa merasa kesulitan menyelesaikan soal pemecahan masalah. Selanjutnya mahasiswa belum terbiasa dan termotivasi untuk mengerjakan soal-soal kemampuan pemecahan masalah, mereka cenderung menyerah lebih dahulu sebelum mencoba menjawab dan lebih memilih mengerjakan soal-soal rutin tentang pemahaman konsep saja. Sebagian mahasiswa tidak memiliki buku referensi dan hanya belajar menunggu materi dari dosen saja. Disamping itu, menurut mahasiswa modul sebagai penunjang atau referensi yang baik sehingga memudahkan mahasiswa untuk mencari dan memahami materi trigonometri.

Data lain yang diperoleh yaitu tentang karakteristik modul yang diinginkan mahasiswa diantaranya adalah modul tersebut harus banyak menyediakan contoh soal pemecahan masalah beserta penyelesaiannya, disajikan juga kunci jawaban untuk memudahkan mahasiswa mencek jawabannya jika salah sebelum bertanya kepada dosen, memiliki tabel atau grafik trigonometri yang akurat dan dapat dipercaya sumbernya, dan memiliki rangkuman yang memudahkan mahasiswa untuk mengingat rumusrumus yang susah atau rumit untuk diingat. Selain itu, modul memuat materi, latihan, soal dan pemahaman konsep yang rinci dan jelas serta pemecahan masalah disertai petunjuk penyelesaian yang dapat dengan jelas mahasiswa pahami.

Karakteristik selanjutnya ialah modul yang menjelaskan konsep pada setiap materi secara detail serta dilengkapi soal-soal pemecahan masalah yang terdiri dari soal mudah sampai soal yang susah. Karakteristik terakhir, yaitu modul yang materi nya runtut dari awal, dan setiap materi langsung ada soal pemecahan masalah nya.

Berdasarkan hasil wawancara juga ditemukan bahwa mahasiswa belum terbiasa dan termotivasi untuk mengerjakan soal-soal kemampuan pemecahan masalah, mereka cenderung menyerah lebih dahulu sebelum mencoba menjawab dan lebih memilih mengerjakan soal-soal rutin tentang pemahaman konsep saja. Hal lain yang diperoleh berdasarkan hasil wawancara dengan guru sebagai pengajar matematika di sekolah ialah materi trigonometri ada di Matematika Wajib kelas X semester 2 dan Matematika Peminatan Kelas XI semester 1 jurusan IPA. Guru menggunakan buku dari penerbit. Guru melatihkan kemampuan pemecahan masalah kepada siswa. Hal terakhir, yaitu menurut guru sangat penting mahasiswa calon guru memiliki kemampuan mengerjakan soal kemampuan pemecahan masalah, sebagai modal dasar seorang calon guru dalam melatihkan pemecahan masalah nantinya kepada siswa.

Berdasarkan hasil wawancara dan survei pendahuluan tersebut didapatkan kesimpulan bahwa kemampuan pemecahan masalah penting untuk dikembangkan dalam pembelajaran trigonometri. Salah satu cara yang efektif menurut mahasiswa sebagai peserta didik untuk mengembangkan kemampuan pemecahan masalah 
DOI: https://doi.org/10.24127/ajpm.v10i1.3375

mahasiswa pada mata kuliah trigonometri adalah dengan menggunakan modul dengan karakterisik modul memuat materi, latihan, soal dan pemahaman konsep yang rinci dan jelas serta pemecahan masalah disertai petunjuk penyelesaian yang dapat dengan jelas dipahami oleh mahasiswa.

\section{b. Analisis Materi}

Berdasarkan hasil wawancara analisis awal akhir didapatkan materi yang perlu dikembangkan pada modul trigonometri ini adalah: 1. Sudut dan pengukurannya; 2. Perbandingan trigonometri; 3. Identitas trigonometri; 4. Rumus jumlah dan selisih sudut; 5 . Sudut rangkap dan sudut pertengahan; 6. Rumus penjumlahan/ pengurangan dan perkalian sinus dan kosinus; 7 . Dalil-dalil segitiga; 8. Persamaan trigonometri.

\section{c. Spesifikasi Tujuan Pembelajaran}

Spesifikasi tujuan pembelajaran merupakan dasar penyusunan rancangan modul trigonometri. Setelah mengikuti pembelajaran menggunakan modul trigonometri mahasiswa dapat: 1.Menentukan ukuran sudut dalam derajat dan radian; 2.Menentukan perbandingan trigonometri pada segitiga siku-siku; 3. Menentukan nilai perbandingan trigonometri pada sudut khusus; 4. Menentukan rumus perbandingan trigonometri untuk sudutsudut berelasi; 5. Membuktikan identitas trigonometri; 6. Menggunakan rumus-rumus trigonometri untuk jumlah dan selisih dua sudut dalam menghitung nilai sudut dan penyelesaian identitas trigonometri; 7. Menggunakan rumusrumus trigonometri untuk sudut rangkap dan sudut pertengahan dalam menghitung nilai sudut dan penyelesaian identitas trigonometri; 8 .
Menggunakan rumus perkalian dan rumus penjumlahan pengurangan sinus dan kosinus dalam menghitung nilai sudut dan penyelesaian identitas trigonometri; 9. Menggunakan dalildalil dalam segitiga aturan sinus, aturan cosinus untuk mencari unsur segitiga yang belum diketahui dan menghitung luas segitiga; 10.Menyelesaikan persamaan trigonometri;

\section{Deskripsi Tahap Perancangan}

Tahap Perancangan, pembuatan dan penulisan draft modul. Modul ini berisi materi trigonometri dilengkapi dengan soal-soal latihan, baik soal pemahaman konsep maupun soal pemahaman pemecahan masalah matematika. Rancangan isi modul ini terdiri atas cover, kata pengantar, daftar isi, judul materi,tujuan pembelajaran, uraian materi, contoh soal materi trigonometri, contoh soal pemecahan masalah, rangkuman, latihan soal pemahaman konsep, panduan menjawab dan uraian cara penyelesaian, latihan soal pemecahan masalah, panduan menjawab dan kunci jawaban, tes ujian akhir bab (soal pemahaman konsep dan pemecahan masalah) dan kunci jawaban. Adapun tampilannya pada modul, dapat dilihat pada Gambar 1, Gambar 2, dan Gambar 3.

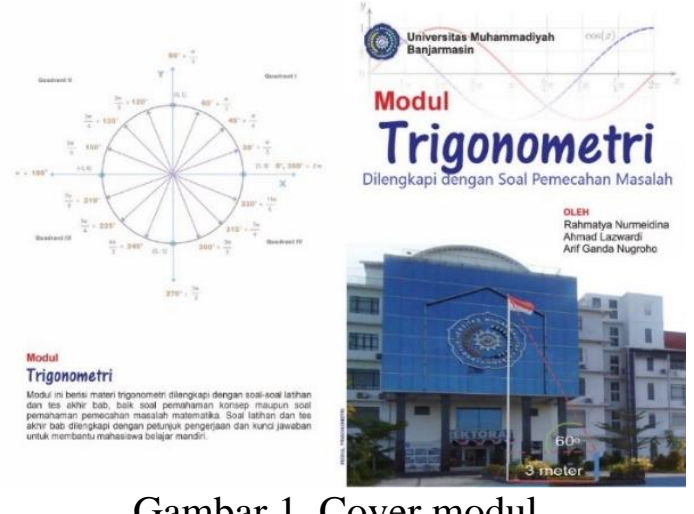

Gambar 1. Cover modul. 
DOI: https://doi.org/10.24127/ajpm.v10i1.3375
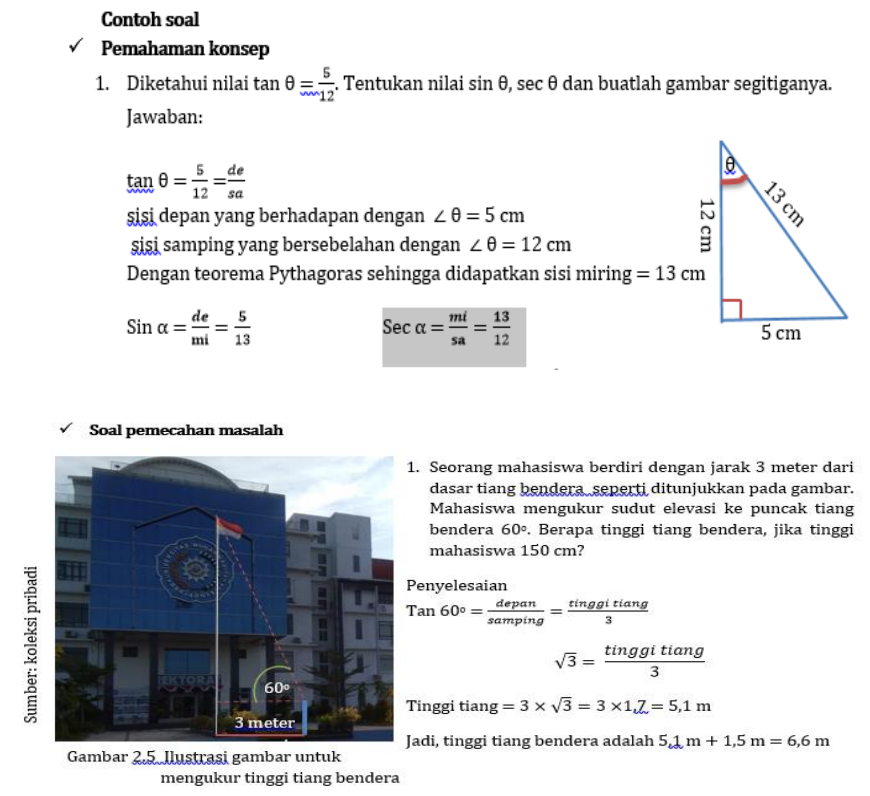

Gambar 2. Contoh soal.

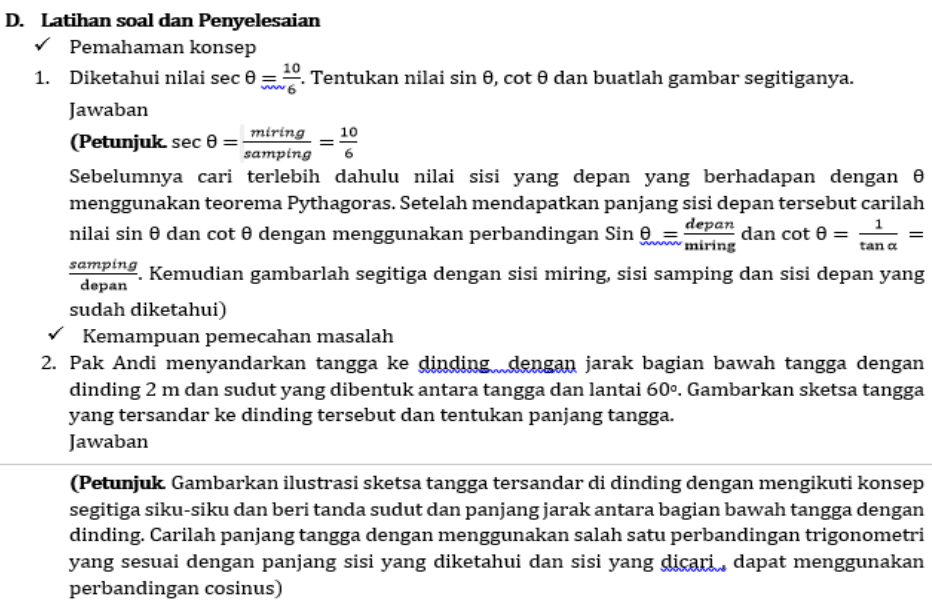

(Petunjuk Gambarkan ilustrasi sketsa tangga tersandar di dinding dengan mengikuti konsep segitiga siku-siku dan beri tanda sudut dan panjang jarak antara bagian bawah tangga dengan dinding. Carilah panjang tangga dengan menggunakan salah satu perbandingan trigonometri yang sesuai dengan panjang sisi yang diketahui dan sisi yang dicari, dapat menggunakan perbandingan cosinus)

Gambar 3. Latihan soal dan petunjuk penyelesaian.

\section{Tahap Pengembangan}

Tahap pengembangan ini terdiri dari penilaian validasi ahli, penilaian kepraktisan mahasiswa terhadap modul trigonometri pada uji coba terbatas dan uji coba lapangan, dan penilaian keefektifan ditinjau dari tes hasil belajar menggunakan soal pemecahan masalah. Modul dirancang dan menghasilkan draft 1.

Tahap selanjutnya adalah melakukan proses validasi ahli oleh dua orang validator. Adapun kualifikasi validator tersebut adalah doktor bidang pendidikan matematika. Proses validasi dilakukan dengan menggunakan lembar validasi dan modul trigonometri. Validasi oleh ahli dilakukan untuk melihat isi draf 1. Lembar validasi terdiri dari 4 aspek yang dinilai yaitu aspek isi modul, bahasa dan tampilan, ilustrasi, letak, tabel \& diagram, dan manfaat. Di bagian bawah lembar validasi disediakan temapat menuliskan 
saran dan komentar secara terbuka untuk selanjutnya direvisi. Selain itu, validator juga dapat menuliskan koreksi langsung pada draft modul yang diberikan. Modul yang sudah selesai diperiksa oleh validator dan dianalisis datanya, kemudian dismpulkan tentang kevalidan modul tersebut. Hasil dari proses validasi oleh ahli dapat dilihat pada Tabel 3.

Tabel 3. Hasil Validasi Ahli

\begin{tabular}{cccc}
\hline Aspek yang dinilai & Validator 1 & Validator 2 & Rata-rata \\
\hline Materi & 3,467 & 3,800 & 3,630 \\
Soal \& Latihan & 3,670 & 3,975 & 3,820 \\
Bahasa \& Tampilan & 3,000 & 3,400 & 3,200 \\
Ilustrasi Tabel & 3,267 & 3,400 & 3,340 \\
Manfaat & 3,467 & 3,730 & 3,600 \\
\hline \multicolumn{3}{c}{ Rata-rata semua aspek } \\
\hline
\end{tabular}

Berdasarkan Tabel 3, aspek soal dan latihan modul merupakan aspek yang memperoleh skor paling tinggi dari validator, sedangkan aspek bahasa dan tampilan mendapatkan skor terendah dari keempat aspek. Rata-rata validasi modul 3,446, artinya modul valid. Setelah melewati proses validasi dan mendapatkan hasil valid dengan sedikit revisi, dilanjutkan ke proses uji kepraktisan dan uji efektifitas ((Hartono $\&$ Noto, 2017).

Selain memberikan penilaian, validator juga memberikan beberapa saran perbaikan yang menjadi bahan pertimbangan untuk memperbaiki draft modul selanjutnya. Hasil komentar dan saran dari validator tersebut dijadikan bahan untuk perbaikan modul draft 1 . Draft 1 yang telah diperbaiki ini, selanjutnya menjadi draft 2 .

\section{Uji Coba Terbatas}

Modul draft 2 ini kemudian dilakukan uji coba terbatas oleh 12 orang mahasiswa yang telah mengambil mata kuliah trigonometri. Mahasiswa tersebut diminta untuk membaca dan memberikan komentar tentang modul yang dibaca sesuai dengan materi yang diminta, kemudian mengisi panduan uji keterbacaan mahasiswa. Data hasil uji coba terbatas mahasiswa berdasarkan hasil isian lembar panduan uji keterbacaan mahasiswa untuk setiap materi dapat dilihat pada Tabel 4.

Tabel 4. Hasil Uji Coba Terbatas

\begin{tabular}{lc}
\hline \multicolumn{1}{c}{ Materi } & Rata-rata \\
\hline Sudut dan ukurannya & 3,69 \\
Perbandingan trigonometri & 3,69 \\
Identitas trigonometri & 3,31 \\
Dalil-dalil segitiga & 3,31 \\
Rumus-rumus trigonometri & 3,42 \\
\hline Rata-rata seluruh bab & $\mathbf{3 , 4 8}$ \\
\hline
\end{tabular}

Berdasarkan tabel 4 dapat dilihat bahwa hasil uji coba terbatas dari modul trigonometri yang dikembangkan diperoleh rata-rata skor 3,480 dari rentang penilaian $1 \mathrm{~s} / \mathrm{d} \quad 4$ dan menunjukkan hasil yang tinggi. Selain 
memberikan penilaian, mahasiswa juga memberikan komentar dan saran. Komentar dan saran tersebut digunakan sebagai masukan dalam revisi modul. Setelah melalui proses uji keterbacaan, draft modul 2 di revisi sesuai dengan saran dan masukan dari mahasiswa. Draft hasil revisi ini disebut draft modul 3. Draft ini akan digunakan untuk proses uji coba lapangan. Sesuai dengan penelitian (Nurmeidina et al., 2020) setelah melalui proses uji keterbacaan draft modul direvisi, kemudian dilanjutkan untuk proses uji coba lapangan. Mahasiswa diberikan modul, proses uji coba dan pembelajaran dilaksanakan secara daring dan dilaksanakan mandiri oleh mahasiswa untuk berlatih soal pada modul.

\section{Uji Coba Lapangan}

Subjek uji coba lapangan adalah mahasiswa semester I yang sedang mengikuti mata kuliah trigonometri. Uji

coba lapangan ini menghasilkan sejumlah data yang dianalisis untuk mengetahui kepraktisan dan keefektifan perangkat pembelajaran yang dikembangkan. Kepraktisan dapat diketahui dari lembar penilaian kepraktisan oleh mahasiswa. Sedangkan keefektifan dapat dilihat dari tes hasil belajar dengan soal pemecahan masalah.

\begin{tabular}{lrr}
$\begin{array}{l}\text { Penilaian } \\
\text { Mahasiswa }\end{array}$ & Kepraktisan & oleh \\
\multicolumn{1}{c}{ Data dari } & lembar & penilaian \\
mahasiswa & digunakan & untuk \\
mengetahui & kepraktisan dari & modul \\
yang dikembangkan. Lembar & penilaian \\
mahasiswa ini & diberikan & kepada \\
Mahasiswa & setelah & selesai \\
melaksanakan & \multicolumn{2}{c}{ pembelajaran } \\
menggunakan modul. Data hasil lembar \\
kepraktisan mahasiswa dapat & dilihat \\
pada Tabel 6 dan Tabel 7.
\end{tabular}

Tabel 6. Penilaian kepraktisan mahasiswa terhadap Modul untuk setiap materi modul

\begin{tabular}{cc}
\hline Materi & Rata-rata \\
\hline Sudut dan ukurannya & 3,8 \\
Perbandingan trigonometri & 3,8 \\
Identitas trigonometri & 3,8 \\
Dalil-dalil segitiga & 3,8 \\
Rumus-rumus trigonometri & 4,0 \\
\hline Rata-rata seluruh bab & $\mathbf{3 , 8 4}$ \\
\hline
\end{tabular}

Tabel 7. Penilaian kepraktisan mahasiswa terhadap Modul dari Aspek penilaian

\begin{tabular}{clc}
\hline No & \multicolumn{1}{c}{ Aspek Penilaian } & $\begin{array}{c}\text { Rata- } \\
\text { rata }\end{array}$ \\
\hline 1 & Jenis tulisan, ukuran huruf dan bahasa & 3,8 \\
2 & Isi modul (gambar, tabel, uraian materi dan rangkuman) & 3,7 \\
3 & $\begin{array}{l}\text { Contoh soal dan latihan melatih kemandirian kemampuan } \\
\text { pemecahan masalah }\end{array}$ & 3,8 \\
4 & $\begin{array}{l}\text { Modul secara umum melatih kemandirian dan kemamapuan } \\
\text { pemecahan masalah }\end{array}$ & 3,8 \\
\hline & \multicolumn{1}{c}{ Rata-rata seluruh aspek } \\
\hline
\end{tabular}


Berdasarkan hasil pada Tabel 6 dan Tabel 7 didapatkan skor rata-rata penilaian mahasiswa terhadap modul untuk setiap materi adalah 3,84 dan ditinjau dari aspek penilaian adalah 3,76. Nilai tersebut termasuk dalam kategori kepraktisan tinggi. Mahasiswa juga merespon positif adanya modul ini karena memudahkan mereka untuk belajar trigonometri. Selain itu, mahasiswa memberikan masukan dan saran mengenai kekeliruan dalam penulisan, ukuran huruf dan angka, dan rincian penjelasan jawban soal

Aspek keefektifan ditinjau dari tes hasil belajar dengan soal pemecahan masalaah. Hasil tes menunjukkan terjadi peningkatan antara hasil pretest dan posttest. Rata-rata hasil pretest 19,01235, sedangkan rata-rata hasil post test 68,6 terjadi peningkatan hasil tes sekitar $27,72 \%$. Sehingga, disimpulkan bahwa hasil pengembangan telah memenuhi aspek keefektifan. Selain itu, diperoleh hasil 70,37\% mahasiswa mendapat nilai diatas 60. Latihan soal pemahaman konsep dan pemecahan masalah pada modul membuat mahasiwa memahami materi dengan baik dan dapat mengembangkan kemampuan pemecahan masalah. Hal ini menunjukkan pembelajaran matematika menggunakan modul efektif (Devesh \& Nasseri, 2014), (Nurmeidina et al., 2020), dan dapat meningkatkan kemampuan pemecahan masalah siswa sekolah (Nasution, 2016),(Sormin \& Sahara, 2019), (Angraini \& Masykur, 2018) dan pemecahan masalah mahasiswa pendidikan matematika (Ismail et al., 2017), (Subekti \& Akhsani, 2020), (Fitri et al., 2015).

Dampak positif dari penelitian ini ditinjau dari 2 aspek, secara terapan dan secara teoritis. Dampak positif secara terapan adalah modul yang dihasilkan dapat memudahkan mahasiswa untuk memahami materi, berminat untuk belajar trigonometri dan dapat memudahkan mahasiswa untuk belajar dan berlatih sendiri. Adanya soal-soal latihan kemampuan pemecahan masalah dan tes hasil belajar dengan kunci jawaban dapat melatih mahasiswa mengevaluasi kinerjanya sendiri dan mengembangkan kemampuan pemecahan masalah. Selanjutnya, dampak penelitian secara teoritis adalah dapat dijadikan acuan dalam pengembangan modul dengan materi lainnya.

\section{KESIMPULAN DAN SARAN}

Dari hasil penelitian dan pengembangan yang dilakukan menghasilkan modul trigonometriyang valid, praktis, efektif dan dapat memefasilitasi siswa dalam mengembangkan kemampuan pemecahan masalah. Aspek kevalidan berdasarkan penilaian ahli menunjukkan bahwa modul pada kategori valid. Aspek kepraktisan berdasarkan penilaian mahasiswa adalah tinggi. Aspek efektifitas berdasarkan tes hasil belajar dengan soal pemecahan masalah mengalami peningkatan dari hasil pretest dan post test. Hasil pengembangan merupakan produk modul pembelajaran mata kuliah trigonometri yang valid, praktis dan efektif dan layak digunakan untuk mahasiswa pendidikan matematika.

Saran untuk penelitian berikutnya adalah dapat melanjutkan penelitian eksperimen untuk mengukur pengaruh penggunaan modul trigonometri ini untuk meningkatkan kemampuan pemecahan masalah mahasiswa pendidikan matematika. Penelitian selanjutnya juga dapat mengembangkan modul trigonometri untuk mengembangkan kemampuan lainnya, baik hardskill maupun softskill. 


\section{UCAPAN TERIMA KASIH}

Terima kasih kepada Direktorat Riset dan Pengabdian Masyarakat Direktorat Jenderal Riset dan Pengembangan, Kementerian Riset, Teknologi, dan Pendidikan Tinggi, LPPM, FKIP, Mahasiswa Pendidikan Matematika Universitas Muhammadiyah Banjarmasin dan seluruh pihak yang telah mendukung dan terlibat dalam penelitian ini.

\section{DAFTAR PUSTAKA}

Ahmad, H., Febryanti, F., Muthmainnah, M., Yakin, A. Al, \& Sarbi, S. (2018). The Analysis of Student Error in Solve the Problem of Spherical Trigonometry Application. Journal of Physics: Conference Series, 1114(1), 0-9. https://doi.org/10.1088/17426596/1114/1/012114

Angraini, N., \& Masykur, R. (2018). Modul Matematika Berdasarkan Model Pembelajaran Problem Based Learning Materi Pokok Trigonometri. Desimal: Jurnal Matematika, $\quad 1(2), \quad 217$. https://doi.org/10.24042/djm.v1i2. 2558

Devesh, S., \& Nasseri, D. A. L. (2014). Effectiveness of Mathematics Module in Foundation Programme in Majan College. International Journal of Emerging Engineering Research and Technology, 2(1), 17.

Fitri, D. Y., Septia, T., \& Yunita, A. (2015). Pengembangan Modul Kalkulus 2 Pada Program Studi Pendidikan Matematika Di Stkip Pgri Sumatera Barat. Jurnal Pelangi, $6(1)$. https://doi.org/10.22202/jp.v6i1.28 8

Hartono, W., \& Noto, M. S. (2017). Pengembangan Modul Berbasis
Penemuan Terbimbing untuk Meningkatkan Kemampuan Matematis pada Perkuliahan Kalkulus Integral. JNPM (Jurnal Nasional Pendidikan Matematika), 1(2), 320. https://doi.org/10.33603/jnpm.v1i2 .616

Hendriana, H., Rohaeti, E. E., \& Sumarmo, U. (2017). Hard Skills dan Soft Skills. In Refika Aditama.

In'am, A. (2015). Menguak penyelesaian masalah matematika (Analisis pendekatan metakognitif dan model polya). AM Publishing.

Ismail, A. D., Jamil, A. F., \& Putri, O. R. U. (2017). Pengembangan Modul Trigonometri Bercirikan Open Ended Problem. AdMathEdu, 7(1), 1-8.

May, V., \& Courtney, S. (2016). Developing meaning in trigonometry. Illinois Mathematics Teacher, 63(1), 25-33.

Nasution, A. (2016). Pengembangan Modul Matematika Berbasis Masalah Untuk Meningkatkan Kemampuan Pemecahan Masalah Matematik Siswa. Rekognisi: Jurnal Pendidikan Dan Kependidikan, 1(1). https://doi.org/10.31604/eksakta.v4 i1.41-48

Nugroho, A. A., Juniati, D., \& Siswono, T. Y. E. (2018). Self regulated learning of prospective mathematics teacher in solving linier program problem : a case of visual learning style. International Conference on Mathematics and Science Education, 3, 820-824.

Nurmeidina, R., Lazwardi, A., \& Ariyanti, I. (2020). Pengembangan Modul Teori Peluang untuk Meningkatkan Hasil Belajar dan Disposisi Matematis. Aksioma, Jurnal Pendidikan Matematika 
DOI: https://doi.org/10.24127/ajpm.v10i1.3375

FKIP Universitas Muhammadiyah Metro, 9(2), 440-450.

Nurmeidina, R., \& Rafidiyah, D. (2019, November 6). Analysis of Students' Difficulties in Solving Trigonometry Problems. https://doi.org/10.4108/eai.7-82019.2288422

Phonapichat, P., Wongwanich, S., \& Sujiva, S. (2014). An Analysis of Elementary School Students' Difficulties in Mathematical Problem Solving. Procedia Social and Behavioral Sciences, 116(February), 3169-3174. https://doi.org/10.1016/j.sbspro.20 14.01 .728

Polya, G. (2004). How to solve it: A new aspect of mathematical method (Vol. 85). Princeton university press.

Sarac, A., \& Aslan-Tutak, F. (2017). The Relationship between Teacher Efficacy, and Students' Trigonometry Self-Efficacy and Achievement. International Journal for Mathematics Teaching and Learning, 18(1), 66-83.
Sormin, M. A., \& Sahara, N. (2019). Pengembangan Modul Pembelajaran Matematika Berbasis Masalah Untuk Meningkatkan Kemampuan Pemecahan Masalah. EKSAKTA : Jurnal Penelitian Dan Pembelajaran MIPA, 4(1), 41-48. https://doi.org/10.31941/delta.v7i1. 920

Subekti, F. E., \& Akhsani, L. (2020). Pengembangan Modul Statistika Deskriptif Berbasis Pemecahan Masalah. AKSIOMA: Jurnal Program Studi Pendidikan Matematika, $9(3), \quad 530$. https://doi.org/10.24127/ajpm.v9i3. 2869

Thiagarajan, S., Semmel, D. S., \& Semmel, M. I. (1976). Instructional development for training teachers of exceptional children: A sourcebook. In Indiana University. https://doi.org/10.1016/00224405(76)90066-2 